\title{
Direct Shoot Bud Differentiation and Plantlet Regeneration from Leaf and Petiole Explants of Begonia tuberhybrida
}

\author{
Shadia Nada ${ }^{1}$, Siva Chennareddy ${ }^{1}$, and Stephen Goldman \\ The University of Toledo, 2801 Bancroft, Toledo, Ohio 43606-3390
}

\author{
Sairam Rudrabhatla ${ }^{2}$, Shobha Devi Potlakayala, \\ Puthyaparambil Josekutty, and Karelia Deepkamal \\ 777 West Harrisburg Pike, Penn State University, Middletown, PA 17057
}

Additional index words. tissue culture, growth regulators, regeneration, ornamental plants

Abstract. We report here an efficient and high-frequency protocol for direct shoot bud differentiation from mature leaves and petioles of greenhouse-grown Begonia tuberhybrida plants. Shoot buds were induced directly on the adaxial surface of leaf tissues from not only at the cut ends, but also across the entire surface of both leaf and petiole segments. The highest frequency of shoot bud formation was $90 \%$, and the maximum number of shoots (132) per leaf explant was achieved with modified Murashige and Skoog (MS) (Murashige and Skoog, 1962) media supplemented with $1.0 \mathrm{mg} \cdot \mathrm{L}^{-1} \alpha$-naphthalene acetic acid (NAA) and $2.0 \mathrm{mg} \cdot \mathrm{L}^{-1}$ thidiazuron (TDZ). In petioles, the highest frequency of shoot buds was $82 \%$. A maximum number of 33 shoots per explant was achieved with $0.5 \mathrm{mg} \cdot \mathrm{L}^{-1} \mathrm{NAA}$ and $2.0 \mathrm{mg} \cdot \mathrm{L}^{-1} \mathrm{TDZ}$. The number of shoots produced in both explants was drastically reduced in the treatment with benzyl-aminopurine (BAP) alone or in combination with NAA and/or TDZ. The regenerated shoots were rooted on MS medium supplemented with $0.5 \mathrm{mg} \cdot \mathrm{L}^{-1} \mathrm{NAA}$. All the elongated shoots developed into complete, rooted plantlets within 3 months. All the plantlets were successfully transferred to soil in pots in the greenhouse and they produced morphologically normal flowers. Chemical names used: $\alpha$-naphthalene acetic acid (NAA), N-phenyl-N'-1,2,3-thiadiazol-5ylurea (TDZ; thidiazuron), 6-benzyl aminopurine (BAP)

Begonias are one of the most popular ornamental plants in the world and are used as garden plants and potted plants, in hanging baskets, and as greenhouse flowers. Many also have large, showy, and long-lasting flowers that vary in color from white and pink to red and yellow. The wholesale value of floriculture crops in the United States was $\$ 3.83$ billion in 2009, among which bedding and garden plants accounts to $\$ 1.81$ billion (data from USDA floriculture crops 2010 summary). California and Florida account for $46 \%$ of the total bedding and garden plants.

The genus Begonia contains $\approx 2000$ species and belongs to the family Begoniaceae. This genus is classified into three general groups by rootstock and includes the tuberous type, the rhizomatous type, and the fibrousrooted type (Kishimoto et al., 2002). A widely cultivated species of the tuberous type, $B$. tuberhybrida, is probably the result of hybridization among several Andean species.

\footnotetext{
Received for publication 1 Feb. 2011. Accepted for publication 11 Mar. 2011.

We greatly acknowledge funding from USDA/ARS grant and Penn State Harrisburg.

${ }^{1}$ Both authors contributed equally to the manuscript. ${ }^{2}$ To whom reprint requests should be addressed; e-mailsvr11@psu.edu.
}

Begonia $\times$ tuberhybrida, generally known as tuberous Begonia, involves numerous strains and cultivars with various plant forms of flower size and color and is one of the most popular flowerpot crops. In addition to ornamental use, the leaves and roots of tuberous Begonias are also used for medicinal purposes (Doskotch and Hufford, 1970; Laferriere, 1992). Begonias are usually propagated by conventional vegetative methods such as stem and leaf cuttings. One of the drawbacks to vegetative propagation by cuttings is this has a low multiplication rate (Peck and Cumming, 1984). In addition, many pathogens such as viruses, bacteria, and fungi can enter plants through cuttings resulting in infection of the plants. To circumvent these problems, in vitro techniques have been explored, albeit in a limited and spotty fashion.

Despite significant advances made in tissue culture in other ornamentals (Debergh et al., 1990; Hedtrich et al., 1983; Teixeira da Silva, 2003; Varshney and Dhawan, 1998), information on Begonia tissue culture and regeneration is limited (Castillo and Smith, 1997; CherngKang and Chih-Cheng, 2009; Espino et al., 2004; Mendi et al., 2009; Takayama, 1990). This is particularly true for Begonia tuberhybrida. In fact, only limited data are available on low-frequency shoot regeneration and rooting from leaves and petioles (Debergh and Maene, 1981; Iida et al., 1986; Kiyokawa et al., 2001; Shimada et al., 2007; Viseur and
Lievens, 1987). Also, micropropagation of Begonia using microshoots has limited scaleup potential. It has been observed that not more than 10 cuttings can be harvested from a single proliferating shoot primordium from a large tuber (Peck and Cumming, 1984). Simmonds and Werry (1987) used liquid shaker culture of Begonia $\times$ hiemalis tissues to separate adventitious buds on petiole explants with limited success. Similarly, Nakano et al. (1999) obtained eight to nine adventitious shoots per explant from both leaf and petiole segments of the "rose-formed" strain of hybrid Begonia tuberhybrida Voss. Thus, the establishment of a robust and efficient plant regeneration protocol for Begonia is important, particularly for the development of transgenic ornamentals, an area where little work has been done.

Hence, we report here a novel and highfrequency protocol for in vitro plant regeneration from leaf and petiole segments of Begonia tuberhybrida through direct shoot bud formation, without intervening callus phase, that resulted in complete regeneration of plantlets within 3 months.

\section{Materials and Methods}

Seeds of Begonia tuberhybrida obtained from the Oglevee Ltd. (Connellsville, PA) were planted in the greenhouse in $15.2-\mathrm{cm}$ pots with four seeds in each pot. Fully expanded leaves with $\approx 3$ - to 4 -cm petioles were excised from healthy plants. The petioles were cut off from the leaf segment and explants were rinsed with a drop of soap in running tap water for $10 \mathrm{~min}$. The explants were then transferred to a flow hood and surface-sterilized by immersing in $70 \%$ ethyl alcohol for $1 \mathrm{~min}$ followed by 10-min incubation in $1 \%$ commercial bleach with intermittent shaking. The explants were subsequently rinsed three times at 5-min intervals in sterile distilled water. Once the explants were surface-sterilized, the exposed cut ends of petioles and leaves were trimmed again and made into $1-\mathrm{cm}$ length pieces in case of petioles and $1-\mathrm{cm}^{2}$ pieces in case of leaves.

The explants were blot-dried between sterile filter papers. The basal medium used for all the experiments was a Murashige and Skoog (1962) mineral formulation containing its standard salts and vitamins, 3\% sucrose, and solidified with $0.56 \%$ agar. In addition, the basal medium was supplemented with $400 \mathrm{mg} \cdot \mathrm{L}^{-1}$ thiamine and $100 \mathrm{mg} \cdot \mathrm{L}^{-1}$ myoinositol to improve regeneration. The $\mathrm{pH}$ of the media was adjusted to 5.8 with $0.1 \mathrm{M}$ $\mathrm{NaOH}$ or $0.1 \mathrm{M} \mathrm{HCl}$ before autoclaving at $121^{\circ} \mathrm{C}$ for $20 \mathrm{~min}$. Explants (leaf and petiole segments) were placed on each petri dish $(100 \times 15 \mathrm{~mm})$ containing $20 \mathrm{~mL}$ of solidified MS medium augmented with different combinations of plant growth regulators (leaf: 1.0 $\mathrm{mg} \cdot \mathrm{L}^{-1} \mathrm{NAA}$ and $2.0 \mathrm{mg} \cdot \mathrm{L}^{-1} \mathrm{TDZ}$; petioles: $0.5 \mathrm{mg} \cdot \mathrm{L}^{-1} \mathrm{NAA}$ and $2.0 \mathrm{mg} \cdot \mathrm{L}^{-1} \mathrm{TDZ}$ ). The explants were incubated in the dark at $24 \pm$ $2{ }^{\circ} \mathrm{C}$ for $3 \mathrm{~d}$ and then transferred to a $16 / 8$-h photoperiod provided by cool-white fluorescent lights at a quantum flux density of 30 $\mu \mathrm{mol} \cdot \mathrm{m}^{-2} \cdot \mathrm{s}^{-1}$. 
Cultures were examined and photographed with a Stereo zoom microscope (OlympusSZX12, Tokyo, Japan). By Day 6 to 7, the petiole and leaf segments became swollen and by Day 15 , shoot buds were visible as dark green protuberances classified as Stage I shoot buds. These developed into Stage II shoots with clearly defined leaves by Day 21 . The shoots were then transferred onto fresh media for another 2 weeks, and all regenerated shoots were separated and subcultured onto elongation medium (MS basal medium supplemented with $0.5 \mathrm{mg} \cdot \mathrm{L}^{-1}$ of $\mathrm{GA}_{3}$ for 3 weeks. The elongated shoots were separated individually and each placed in a rooting medium [MS basal medium containing $0.5 \mathrm{mg} \cdot \mathrm{L}^{-1}$ of indole3 -acetic acid (IAA)] for 3 weeks and all rooted plantlets were transferred to the greenhouse.

Each treatment consisted of, in the case of leaves, 10 explants and five replications and, in the case of petioles, five explants and five replications. The percentage of explants with shoots and mean number of shoots per explant were recorded after 4 weeks of culture for each treatment and replication. Percentage data were subjected to arcsine transformation for real numbers before analyses by analysis of variance and then converted back to percentages for presentation in the figures according to Snedecor and Cochran (1968). Treatment means were statistically compared using Duncan's new multiple range test (Duncan, 1955). Statistical analysis was done separately for leaf and petiole explants.

\section{Results and Discussion}

In the current study, shoots were induced directly from leaf and petiole segments of mature plants of Begonia. Leaf and petiole explants enlarged in size and turned dark green within 2 weeks of culturing. After $7 \mathrm{~d}$ in culture, proliferation of new cells at the cut ends of leaves was observed (Fig. 1A). These cells continued to divide, forming a group of small cells. After $15 \mathrm{~d}$ in culture, this group of cells became pronounced and could easily be identified as meristematic, the precursors to adventitious shoot buds (Figs. 1B and E). Continued proliferation of small meristemoid cells resulted in rapid expansion of the surface area and the total tissue volume. A consequence of this expansion of cell mass was protrusion of a bud primordium above the leaf and petiole surface, which became visible after 3 weeks in culture (Figs. 1C and G). After $30 \mathrm{~d}$, the bud primordia progressed into the early stage of adventitious shoot bud development (Figs. 1D and F). Shoot buds emerged directly from the surface of the leaves and petioles not only at the cut ends, but also across the entire surface as small green protuberances within 2 weeks (Figs. 1C, F, and G). Although the early events during the development of an adventitious shoot meristem are still largely unknown, the ratio of auxin to cytokinin appears to be one of the factors affecting the pattern of morphogenesis from petiole and leaf explants (Thorpe, 2004).

The type and concentration of cytokinins added to the medium had a significant effect
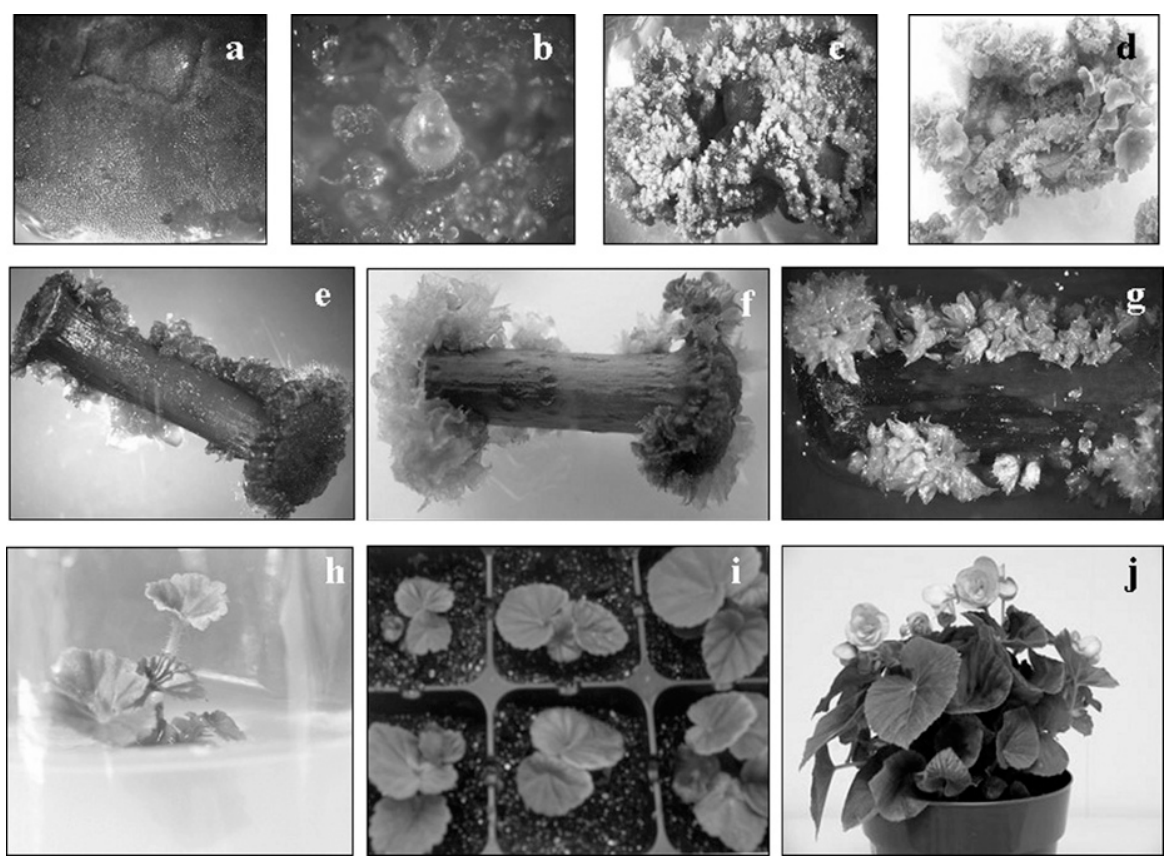

Fig. 1. Different stages of shoot bud induction and plantlet regeneration from leaf and petiole explants of Begonia tuberhybrida. (A) A 7-d-old leaf showing cell expansion at cut ends. (B) Shoot buds originating from leaf explant. (C) Shoot buds all over the leaf explant. (D) Shoot buds expanding on the leaf. (E) Shoot buds originating from cut ends and all over the petiole explant. (F) Plantlets originating from cut ends of petiole. (G) Shoot buds all over the petiole explant. (H) Elongation of shoots. (I) Rooted plantlets in soil. $(\mathbf{J})$ Regenerated plant in flowering.

on shoot bud induction in both leaf and petiole explants. Statistically significant differences between treatments were observed. Thidiazuron was more effective than BAP. In the absence of auxin, no shoot bud differentiation was observed at $1.0 \mathrm{mg} \cdot \mathrm{L}^{-1} \mathrm{BAP}$ in either leaves or petioles (Figs. 2 and 3). In contrast, $2 \%$ shoot buds were observed only in the leaves and not in the petioles in media supplemented with $2.0 \mathrm{mg} \cdot \mathrm{L}^{-1} \mathrm{BAP}$. When BAP was substituted with $1.0 \mathrm{mg} \cdot \mathrm{L}^{-1} \mathrm{TDZ}, 4 \%$ of leaves produced shoot buds. At $2.0 \mathrm{mg} \cdot \mathrm{L}^{-1} \mathrm{TDZ}$, the percentage of leaves producing shoot buds increased to $10 \%$. In case of petioles, $16 \%$ of them showed buds with $1.0 \mathrm{mg} \cdot \mathrm{L}^{-1} \mathrm{TDZ}$. This frequency increased to $20 \%$ at $2.0 \mathrm{mg} \cdot \mathrm{L}^{-1}$ TDZ. The differences between single treatments and combination treatments of BAP and TDZ were statistically significant (Figs. 2 and $3)$. In combination treatments of BAP (1.0 $\left.\mathrm{mg} \cdot \mathrm{L}^{-1}, 2.0 \mathrm{mg} \cdot \mathrm{L}^{-1}\right)$ and TDZ $\left(1.0 \mathrm{mg} \cdot \mathrm{L}^{-1}, 2.0\right.$ $\left.\mathrm{mg} \cdot \mathrm{L}^{-1}\right)$, an additive effect was observed for shoot bud induction in case of leaves, whereas in the case of petioles, an additive effect was observed only at higher concentrations compared with single treatments (Figs. 2 and 3).

In the presence of auxin (NAA), the highest frequency of shoot bud formation was achieved in leaf. When the modified MS was supplemented with $1.0 \mathrm{mg} \cdot \mathrm{L}^{-1} \mathrm{NAA}$ and $2.0 \mathrm{mg} \cdot \mathrm{L}^{-1}$ TDZ, $90 \%$ of the leaf explants produced buds (Figs. 2 and 3). Petioles gave a similar robust response to optimizing the balance between cytokinins and auxin. Eighty-two percent of the petioles produced shoot buds when the growth medium was supplemented with $0.5 \mathrm{mg} \cdot \mathrm{L}^{-1}$ NAA and $2.0 \mathrm{mg} \cdot \mathrm{L}^{-1}$ TDZ (Figs. 2 and 3 ). With increasing concentrations of both NAA and
TDZ, an increase in shoot bud differentiation was observed in both leaf and petiole. The differences for shoot bud induction in both leaf and petiole explants between the combination treatments of NAA + TDZ and NAA + BAP were statistically significant (Figs. 2 and 3). In combination treatments of NAA and BAP, the frequency of shoot bud induction in both leaf and petiole explants increased with increasing concentration of NAA up to 0.5 $\mathrm{mg} \cdot \mathrm{L}^{-1} \mathrm{NAA}$ and then decreased with further increase in NAA concentration (1.0 $\left.\mathrm{mg} \cdot \mathrm{L}^{-1}\right)$. With increase in concentration of BAP also, the frequency of shoot bud induction decreased. In leaves, the highest frequency was $42 \%$ with $0.5 \mathrm{mg} \cdot \mathrm{L}^{-1} \mathrm{NAA}$ and $1.0 \mathrm{mg} \cdot \mathrm{L}^{-1} \mathrm{BAP}$, whereas in petioles, the highest frequency was $36 \%$ with $0.5 \mathrm{mg} \cdot \mathrm{L}^{-1}$ NAA and $2.0 \mathrm{mg} \cdot \mathrm{L}^{-1}$ BAP (Figs. 2 and 3 ).

If the concentrations of TDZ and BAP (1.0 $\left.\mathrm{mg} \cdot \mathrm{L}^{-1}\right)$ are held constant and combined in a medium in which the concentration of NAA increasingly varies, an increase in the frequency of shoot bud induction was observed from leaf explants (Figs. 2 and 3). Bud induction maximized at $50 \%$ at $1.0 \mathrm{mg} \cdot \mathrm{L}^{-1} \mathrm{NAA}$. In contrast, petiole bud formation maximized at $48 \%$ in $0.05 \mathrm{mg} \cdot \mathrm{L}^{-1} \mathrm{NAA}$ and then decreased with increases in auxin to a minimum of $36 \%$ shoot bud induction at $1.0 \mathrm{mg} \cdot \mathrm{L}^{-1}$. Increasing TDZ and BAP to $2.0 \mathrm{mg} \cdot \mathrm{L}^{-1}$ with simultaneous, increasing concentrations of NAA resulted in an increase in shoot bud induction. In the case of leaf explants, shoot bud formation increased to $60 \%$ at $1.0 \mathrm{mg} \cdot \mathrm{L}^{-1}$ NAA. Similar trend was observed in case of petioles also, the maximum being $64 \%$ at 1.0 $\mathrm{mg} \cdot \mathrm{L}^{-1}$ NAA (Fig. 3) 


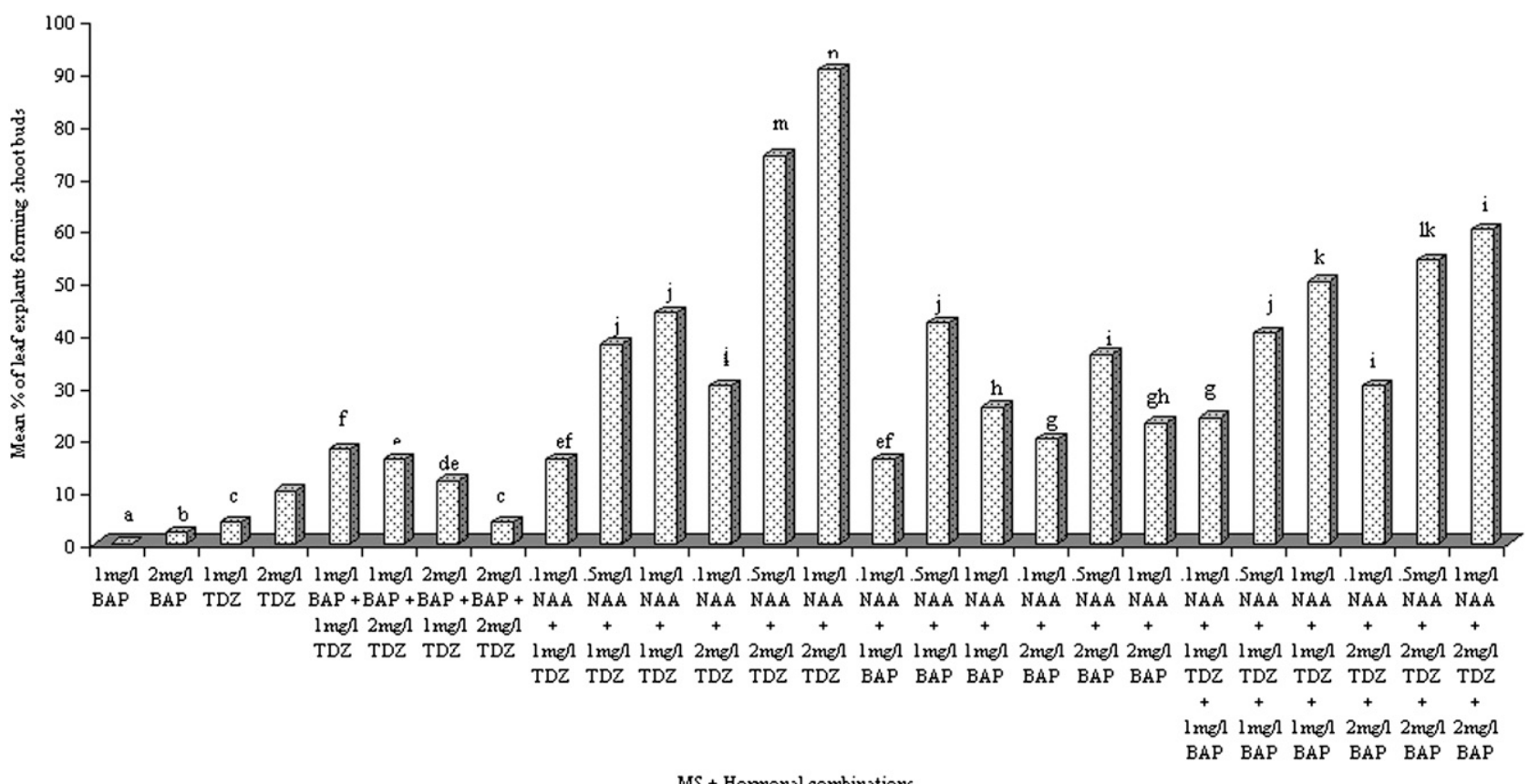

Fig. 2. Effect of $\alpha$-naphthalene acetic acid (NAA), 6-benzyl aminopurine (BAP), thidiazuron, N-phenyl-N'-1,2,3-thiadiazol-5ylurea (TDZ), and their combinations on direct shoot bud induction from leaf explants of Begonia tuberhybrida. The means are average percentages of five replications. Means followed by the same letter are not significantly different from each other at $P<0.05$ according to Duncan's new multiple range test.

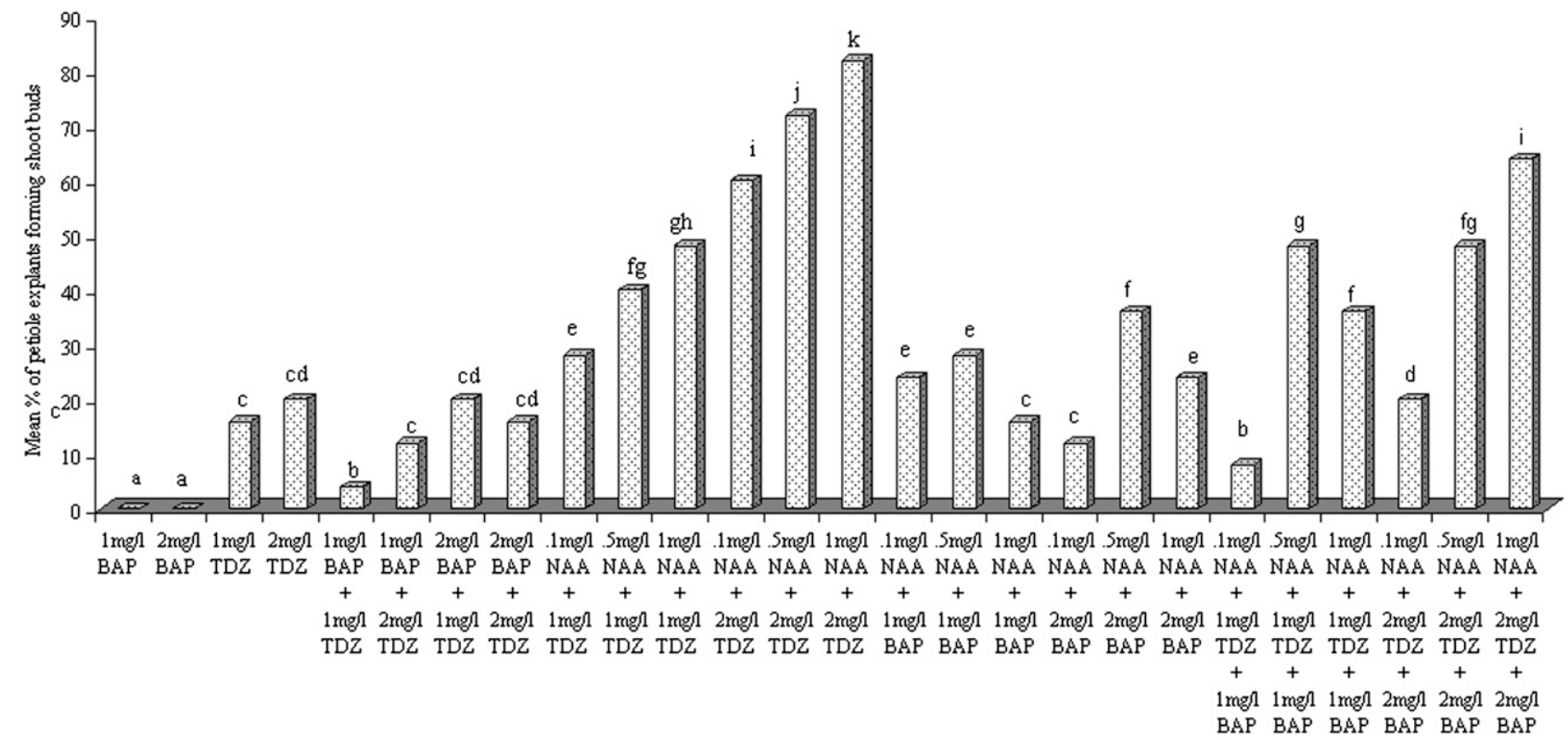

MS + Hormonal Combinations

Fig. 3. Effect of $\alpha$-naphthalene acetic acid (NAA), 6-benzyl aminopurine (BAP), thidiazuron, N-phenyl-N'-1,2,3-thiadiazol-5ylurea (TDZ), and their combinations on direct shoot bud induction from petiole explants of Begonia tuberhybrida. The means are average percentages of five replications. Means followed by the same letter are not significantly different from each other at $P<0.05$ according to Duncan's new multiple range test.

Nakano et al. (1999) also reported a low frequency of shoot bud induction from leaf explants when BAP was used alone in Begonia tuberhyrida. Increases of shoot bud formation were observed only when NAA was added, albeit at a far lower incidence then reported here. In this connection, only eight to nine shoots are reported per leaf explant on media containing $0.1 \mathrm{mg} \cdot \mathrm{L}^{-1} \mathrm{NAA}$ in combination with $0.1 \mathrm{mg} \cdot \mathrm{L}^{-1}$ BAP. Espino et al. (2004) studied the effect of BAP and NAA in four different genotypes of Begonia and likewise reported a low frequency of shoots (one to 10) per leaf explant that was further influenced by genotype in the ability to regenerate in BAP-containing media.

These results reported here, in addition to those reported earlier, indicate a defining role for cytokinins and auxins as function of type, concentration, and combination in the differentiation process. Optimum concentrations of TDZ $\left(2.0 \mathrm{mg} \cdot \mathrm{L}^{-1}\right)$ combined with an auxin
(1.0 $\mathrm{mg} \cdot \mathrm{L}^{-1} \mathrm{NAA}$ ) induced the highest frequency of direct shoot buds both from leaf $(90 \%)$ and petiole ( $82 \%)$ explants. When BAP was substituted for TDZ, there were significant reductions in the incidence of shoot bud differentiation (Figs. 2 and 3 ).

Routine applications of cytokinin were insufficient to induce shoot bud differentiation on leaf and petiole explants of Begonia. In the current study, BAP alone and in combination with various concentrations and combinations 
of NAA and TDZ had an adverse effect in that the number of adventitious shoot buds decreased and shoot growth and development were completely disturbed. However, the combinations of low auxin concentration (NAA, $0.1 \mathrm{mg} \cdot \mathrm{L}^{-1}$ ) along with BAP promoted adventitious shoot bud formation.

In single or combination treatments of BAP and TDZ, a low number of shoots per leaf or petiole explant was observed (Figs. 4 and 5). Statistically significant differences between combination treatments of BAP + $\mathrm{TDZ}$ or NAA + TDZ + BAP were observed for induction of number of shoots per leaf and petiole explants. A maximum of 8.4 shoots/leaf and 6.8 in case of petioles resulted at $2.0 \mathrm{mg} \cdot \mathrm{L}^{-1}$ BAP and $1.0 \mathrm{mg} \cdot \mathrm{L}^{-1} \mathrm{TDZ}$ (Figs. 4 and 5), whereas in the presence of NAA, the number of shoots per leaf or petiole explant increased with increasing concentrations of NAA and TDZ. A maximum of 132 shoots per leaf explant and 33 per petiole explant was noted at $1.0 \mathrm{mg} \cdot \mathrm{L}^{-1}$ NAA and $2.0 \mathrm{mg} \cdot \mathrm{L}^{-1}$ TDZ (Figs. 4 and 5). When BAP was substituted for TDZ in combination with NAA, however, a low frequency of shoots was observed with the maximum being 8.2 per leaf and 9.6 per petiole when treated with $0.5 \mathrm{mg} \cdot \mathrm{L}^{-1} \mathrm{NAA}$ and $1.0 \mathrm{mg} \cdot \mathrm{L}^{-1}$ BAP (Figs. 4 and 5). Similarly, in combination treatments of NAA, BAP, and TDZ, the number of shoot per leaf or petiole explant decreased drastically compared with treatment with NAA and TDZ. These results indicate that BAP interacted with TDZ and reduced the number of shoots per explant (Figs. 4 and 5).

Thidiazuron, a substituted phenylurea that is commercially used as a defoliant for cotton plants to drop green leaves prematurely

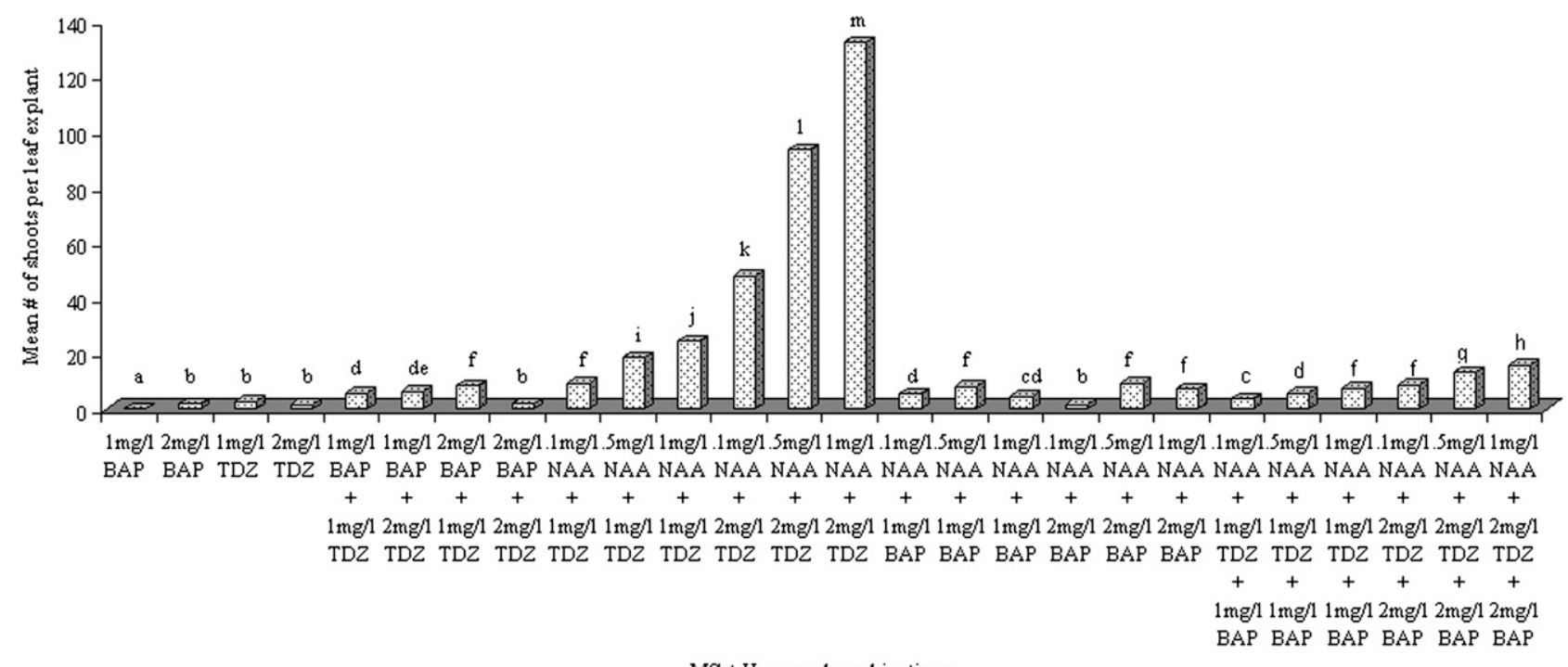

Fig. 4. Effect of $\alpha$-naphthalene acetic acid (NAA), 6-benzyl aminopurine (BAP), thidiazuron, N-phenyl-N'-1,2,3-thiadiazol-5ylurea (TDZ), and their combinations on number of shoots per leaf explant of Begonia tuberhybrida. The means are average percentages of five replications. Means followed by the same letter are not significantly different from each other at $P<0.05$ according to Duncan's new multiple range test.

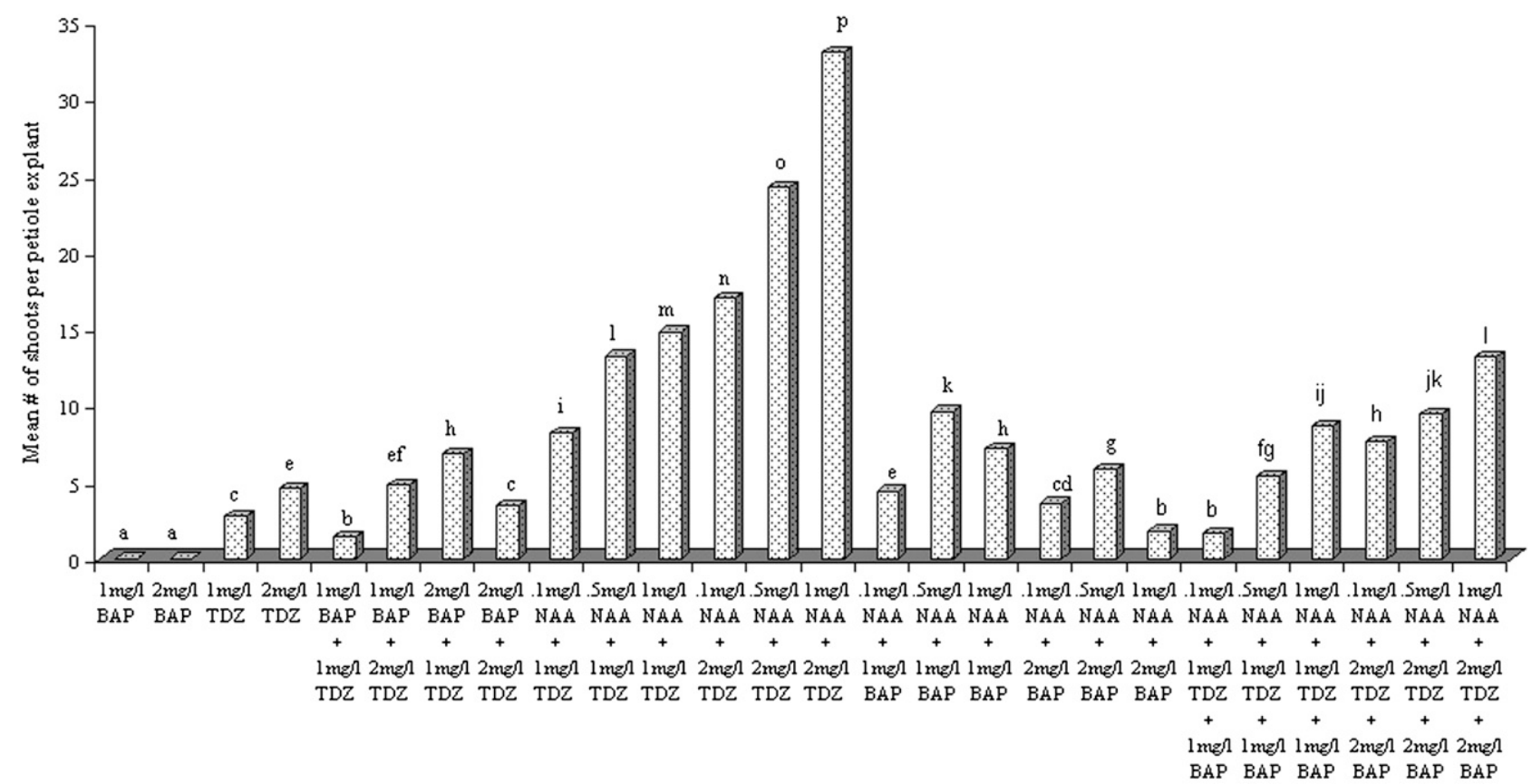

MS + Hormonal combinations

Fig. 5. Effect of $\alpha$-naphthalene acetic acid (NAA), 6-benzyl aminopurine (BAP), thidiazuron, N-phenyl-N'-1,2,3-thiadiazol-5ylurea (TDZ), and their combinations on number of shoots per petiole explant of Begonia tuberhybrida. The means are average percentages of five replications. Means followed by the same letter are not significantly different from each other at $P<0.05$ according to Duncan's new multiple range test. 
for easier harvest of cotton bolls, has been shown to exhibit strong cytokinin-like activity in several culture systems, similar to that of $\mathrm{N}^{6}$-substituted adenine derivatives (Mok et al., 1987; Thomas and Katterman, 1986). Thidiazuron has been reported to induce shoot regeneration in some recalcitrant legumes and from leafy explants of many dicots (Huetteman and Preece, 1993; Malik and Saxena, 1992). This hormone has also been reported to cause embryo differentiation in tobacco leaf discs (Gill and Saxena, 1993), geranium hypocotyls (Visser et al., 1992), and petiole cultures of Pelargonium $\times$ hortorum (Haensch, 2004). Pati et al. (2004) reported the formation of adventitious buds directly on the base of petiole in a medium containing $1.5 \mathrm{mg} \cdot \mathrm{L}^{-1} \mathrm{TDZ}$ and 0.05 $\mathrm{mg} \cdot \mathrm{L}^{-1}$ NAA in Rosa damascene. The mechanisms of action of TDZ are not completely understood and have been reviewed by Murthy et al. (1998). TDZ may be involved in the reprogramming and expression of the competent cells necessary for them to undergo differentiation and development. TDZ was found to induce synthesis or accumulation of endogenous cytokinins (Hare and Van Staden, 1994; Murch and Saxena, 2001; Murthy et al., 1998; Thomas and Katterman 1986). This may result from several possibilities: inhibition of cytokinin degradation by cytokinin oxidase; an increase in synthesis; an increase in catabolism; or a conversion of storage forms to biologically active cytokinins. These results indicate that adventitious bud formation may be triggered by cytokinin synthesized in other parts of the plant or as a result of cytokinin uptake from the media.

The shoot bud differentiation was observed in $\approx 2$ weeks on both leaf and petiole explants. The number of shoot buds per leaf explant varied from 200 to 250 , whereas for the petiole explant, it was from 75 to 100 . Even after the subculture, however, most of them showed little elongation. These small shoots were difficult to excise from the explant. After the second subculture, the elongated shoots were easy to excise and could be transferred to rooting media. It has been reported for Begonia as a species (Nakano et al., 1999) that, although a large number of adventitious shoots can be obtained from single explants, most of them are too small for excision (Peck and Cumming, 1984; Simmonds and Werry, 1987). In the current study, however, the combination treatments of NAA and TDZ had a maximum of 132.2 shoots that could be recovered from leaf explant and 33 shoots from petiole explants, which subsequently regenerated into robust plants lacking any evidence of somaclonal variation. This result stands in stark contrast to previous studies. Espino et al. (2004) and Nakano et al. (1999) reported only eight to nine shoots per leaf in Begonia tuberhybrida and up to eight shoots in B. eliator, $B$. semperflorens, and B. tiger, respectively. Although tissue culture methods and conditions for different Begonia have been reported, their requirements of growth regulators are defining. The number of buds in these studies appears to have been influenced by the different plant hormones. In particular, several investigators have shown that diverse auxin and cytokinin concentrations and/or combinations are required in different species (Thorpe, 2004). The mechanism(s) that allow different genotypes of the same species to discriminate often subtle differences among growth regulators is unknown.

Moreover, this study shows the shoot buds appeared not only at the cut ends of the leaf and petiole explants, but also across the entire surface of the explants. This growth pattern suggests that cytokinin transport through tissues might also play a role in the in vitro response to this class of hormone. In some cases, tissues or cells that responded during the induction of in vitro shoot organogenesis were not in contact with the hormones in the induction media. Recent genetic and molecular studies have indicated that the induction by cytokinin appears to occur up through regulation of expression of certain key regulatory genes involved in differentiation. Different types of genes may be expressed at different developmental stages, ranging from initial hormone response to late shoot meristem development (Haberer and Kieber, 2002).

The combination of high auxin (NAA) concentration $\left(1.0 \mathrm{mg} \cdot \mathrm{L}^{-1}\right)$ with high TDZ concentration $\left(2.0 \mathrm{mg} \cdot \mathrm{L}^{-1}\right)$ led to regeneration of many buds distributed all along the petiole and leaf explants. It is likely that regenerationinhibiting factors exist in the tissues surrounding the wounded portions of leaf and petiole explants from where the regeneration of buds occurs. The presence of auxin in the medium reduces this inhibition, although many other groups are currently exploring its basis. Nevertheless, it is unambiguously clear that the leaf and petiole explants can respond significantly to shoot regeneration factors such as cytokinin in the presence of auxin.

The process of de novo organogenesis is known to involve three steps: the acquisition of competence; shoot induction; and organogenesis determination (Christianson and Warnick, 1988). The plant cells first acquire competence and then, after induction by a phytohormone signal, form a population of developmentally determined cells. Subsequently, morphogenesis proceeds independently of exogenously supplied hormones (Sugiyama, 1999). In the current study, the shoots regenerated directly from leaf and petiole explants were successfully separated and transferred to shoot elongation media containing MS basal medium supplemented with $0.5 \mathrm{mg} \cdot \mathrm{L}^{-1} \mathrm{GA}_{3}$ (Fig. $1 \mathrm{H}$ ).

Both full-strength MS and half-strength MS medium supplemented with $0.5 \mathrm{mg} \cdot \mathrm{L}^{-1}$ IAA were used for rooting of in vitro-regenerated shoots. All of the regenerated shoots that were placed on to MS medium supplemented with $0.5 \mathrm{mg} \cdot \mathrm{L}^{-1}$ IAA formed roots within 2 weeks. No roots were formed on shoots on incubated on medium devoid of growth regulators. The regenerated plants with roots were transferred to 25-hole trays filled with soil medium and acclimatized in the growth chamber for 2 to 3 weeks at $24{ }^{\circ} \mathrm{C}$ and $80 \%$ humidity under a 16/8-h photoperiod and then transferred to the green house (Fig. 1I). All regenerated plants that were obtained from leaves or petioles through direct shoot bud differentiation had the same morphology and flowering as the parental clone (Fig. 1J).

This protocol holds great promise for micropropagation and genetic transformation studies in Begonia for achieving broadspectrum disease resistance and cold tolerance.

\section{Literature Cited}

Castillo, B. and M.A.L. Smith. 1997. Direct somatic embryogenesis from Begonia gracilis explants. Plant Cell Rep. 16:385-388.

Cherng-Kang, L. and S. Chih-Cheng. 2009. Adventitious shoot induction and plant regeneration of hybrid tuberous begonia (Begonia $\times$ tuberhybrida Voss). J. of the Agr. Assn. of Taiwan. 10:102-113. Christianson, M.I. and D. Warnick. 1988. Organogenesis in vitro as developmental process. HortScience 23:515-519.

Debergh, P. and L.J. Maene. 1981. A scheme for commercial propagation of ornamental plants by tissue culture. Sci. Hort. 14:335-345.

Debergh, P., J. Rogyemans, and S.D. Metsenaer. 1990. Tissue culture in relation to ornamentals, p. 161-189. In: Bhojwani, S.S. (ed.). Plant tissue culture applications and limitations. Elsevier Sci. Publ., B.V. Amsterdam, The Netherlands.

Doskotch, R.W. and C.D. Hufford. 1970. Hexanorcucurbitiacin D, a degraded cucurbitacin from Begonia tuberhybrida.. Can. J. Chem. 48:17871788.

Duncan, D.B. 1955. Multiple range and multiple Ftests. Biometrics 11:1-42.

Espino, F.J., R. Linacero, J. Rueda, and A.M. Vasquez. 2004. Shoot regeneration in four Begonia genotypes. Biol. Plant. 48:101-104.

Gill, R. and P.K. Saxena. 1993. Somatic embryogenesis in Nicotiana tobaccum L. Induction by thidiazuron of direct embryo differentiation from cultured leaf discs. Plant Cell Rep. 12:154-159.

Haberer, G. and J.J. Kieber. 2002. Cytokinins, new insights into a classical phytohormone. Plant Physiol. 128:354-362.

Haensch, K.T. 2004. Thidiazuron-induced morphogenetic response in petiole cultures of Pelargonium $\times$ hortorum and Pelargonium $\times$ domesticum and its histological analysis. Plant Cell Rep. 23:211-217.

Hare, P.D. and J.E. Van Staden. 1994. Inhibitory effect of thidiazuron on the activity of cytokinin oxidase isolated from soybean callus. Plant Cell Physiol. 35:1121-1125.

Hedtrich, T.R., T.C.M. Hedtrich, and J.R. Mayer. 1983. The use of tissue culture for the production of ornamental plants: Some economical aspects. Acta Hort. 131:179-192.

Huetteman, C.A. and J.E. Preece. 1993. Thiadiazuron: A potent cytokine for woody plant tissue culture. Plant Cell Tissue Organ Cult. 33:105-109.

Iida, T., K. Yabe, S. Washida, and Y. Sakurai. 1986. Propagation of tuberous Begonia by tissue culture. Research Bulletin of the Aichiken Agr. Res. Ctr. 18:186-190.

Kishimoto, S., R. Aida, and M. Shibata. 2002 Agrobacterium tumefaciens mediated transformation of eliator Begonia (Begonia $\times$ hiemalis Fotsch). Plant Sci. 162:697-703.

Kiyokawa, S., Y. Kikuchi, H. Kamada, and H. Harada. 2001. Transgenic Begonia, p. 43-54. In: Bajaj, Y.P.S. (ed.). Transgenic crops III. Biotechnol. in Agr. and For. Vol. 48. SpringlerVerlag, Berlin, Heidelberg, Germany.

Laferriere, J.E. 1992. Begonia as food and medicine. Soc. for Econ. Bot. 46:114-116.

Malik, K.A. and P.K. Saxena. 1992. Thiadiazuron induces high frequency shoot regeneration in intact seedlings of pea (Pisum sativum), 
chickpea (Cicer arietinum) and lentil (Lens culnaris). Aust. J. Plant Physiol. 19:731-740.

Mendi, Y.Y., P. Curuk, E. Kocaman, C. Unek, S. Eldogan, G. Gencel, and S. Cetiner. 2009. Regeneration of begonia plantlets by direct organogenesis. Afr. J. Biotechnol. 8:1860-1863.

Mok, M.C., D.W.S. Mok, J.E. Turner, and C.V. Mujer. 1987. Biological and biochemical effects of cytokinin-active phenylurea derivatives in tissue culture systems. Sci. Hort. 22:1194-1196.

Murashige, T. and F. Skoog. 1962. A revised medium for rapid growth and bioassays with tobacco cultures. Plant Physiol. 15:473-497.

Murch, S.J. and P.K. Saxena. 2001. Molecular fate of thidiazuron and its effects on auxin transport in hypocotyls tissue of Pelargonium $\times$ hortorum bailey. Plant Growth Regulat. 35:269-275.

Murthy, B.N.S., S.J. Murch, and P.K. Saxena. 1998. Thidiazuron: A potent regulator of in vitro plant morphogenesis. In Vitro Cell. Dev. Biol. Plant 34:267-275.

Nakano, M., Y. Nimi, D. Kobayashi, and A. Watanabe. 1999. Adventitious shoot regeneration and micropropagation of hybrid tuberous
Begonia $($ Begonia $\times$ tuberhybrida voss). Sci. Hort. 79:245-251.

Pati, P.K., M. Sharma, A. Sood, and P.S. Ahuja. 2004. Direct shoot regeneration from leaf explants of Rosa damascena Mill. In Vitro Cell. Dev. Biol. Plant 40:192-195.

Peck, D.E. and B.G. Cumming. 1984. In vitro propagation of Begonia tuberbybrida from leaf sections. HortScience 19:395-397.

Shimada, Y., G. Mori, M. Oda, and G. Ishida. 2007. Effects of BA and leaf piece orientation on adventitious bud formation in leaf cutting of Begonia tuberhybrida hroup. J. Jpn. Soc. Hort. Sci. 76:157-162.

Simmonds, J.A. and T. Werry. 1987. Liquid shake culture for improved micropropagation of $\mathrm{Be}$ gonia $\times$ hiemalis. HortScience 22:122-124.

Snedecor, G.W. and W.G. Cochran. 1968. Statistical methods. IBH Publishing Co. Pvt. Ltd., Oxford, UK, and Delhi, India.

Sugiyama, M. 1999. Organogenesis in vitro. Curr. Opin. Plant Biol. 2:61-64.

Takayama, S. 1990. Begonia, p. 253-283. In Ammirato, P.V., D.A. Evans, W.R. Sharp, and
Y.P.S. Bajaj (eds.). Hdbk. of Plant Tissue Cult. MacMillan, New York, NY.

Teixeira da Silva, J.A. 2003. Thin cell layer technology in ornamental plant micropropagation and biotechnology. Afr. J. Biotechnol. 2:683-691.

Thomas, J.C. and F.R. Katterman. 1986. Cytokinin activity induced by TDZ. Plant Physiol. 81: 681-683.

Thorpe, T.A. 2004. Turning point article: To root or not to root, that is the question: Reflections of a developmental plant physiologist. In Vitro Cell. Dev. Biol. Plant 40:128-142.

Varshney, A. and V. Dhawan. 1998. Micropropagation of ornamental plants, p. 402-528. In: Srivastava, P.S. (ed.). Plant tissue culture and molecular biology. Applications and prospects. Narosa Publishing House, New Delhi, India.

Viseur, J. and C. Lievens. 1987. In vitro propagation and regeneration of plants from calluses of Begonia tuberhybrida. Acta Hort. 212: 705-709.

Visser, C., J.A. Qureshi, R. Gill, and P.K. Saxena. 1992. Morphogenicity role of thiadiazuron. Plant Physiol. 99:1704-1707. 